\title{
THE RISE AND DESCENT OF VISIONS FOR E-GOVERNMENT
}

\author{
Helle Zinner Henriksen \\ Jan Damsgaard \\ Copenhagen Business School \\ Frederiksberg, Denmark
}

\begin{abstract}
Most nations have defined strategies for e-government. The objectives for implementing e-government are often defined but the means for fueling the adoption and diffusion of e-government are typically less clear in policy statements. The present study assesses the impact of the Danish eDay initiative. The eDay initiative simply yet powerfully states that one governmental authority has the right to demand that its communication with another authority must be in electronic format. The eDay initiative represents a drastic change in the former policy statements concerning IT adoption and diffusion in Danish government. Policy statements had previously been based on voluntary adoption based on indirect and pedagogical intervention in governmental agencies, but eDay marked a departure and the carrot has been exchanged by the stick and the voice is imperative.
\end{abstract}

Keywords e-Government, business process reengineering, information society

\section{INTRODUCTION}

The advent of digital government or electronic government (e-government) has rapidly spread throughout the world leading to a constant stream of policy documents on e-government visions from national and supranational agencies. Representing the supranational agencies, the European Union and the Organisation for Economic Cooperation and Development are among those which have launched visions for egovernment (EU 2003; OECD 2003). Canada and the United States are often claimed to be among the most salient examples of nations that have gone beyond visions and actually implemented effective e-government (Holden et al. 2003; Kaylor et al. 2003). Asian countries such as Malaysia and Singapore have also proven to be in the lead with respect to effective implementation of e-government agendas (Tan and Pan 2003).

\footnotetext{
Please use the following format when citing this chapter:

Henriksen, Helle Zinner, Damsgaard, Jan, 2006, in International Federation for Information Processing (IFIP), Volume 206, The Transfer and Diffusion of Information Technology for Organizational Resilience, eds. B. Donnellan, Larsen T., Levine L., DeGross J. (Boston: Springer), pp. $275-289$
} 
However, in a number of international rankings, the Scandinavian countries are among the forerunners in e-government (Accenture 2005; Cap Gemini 2005; UN 2004). This paper provides a description and analysis of the visions and strategies in one of the Scandinavian countries (Denmark) which may serve as a measure of which strategy yields what effects.

A common characteristic of the above-mentioned agendas and rankings is the citizen centric approach. It is an approach focusing on how governments have or are supposed to adopt IT-tools in order to provide better and faster services to citizens and businesses. A number of maturity models for e-government have been developed in the slipstream of this discourse (Kaylor et al. 2000; Layne and Lee 2001; Moon 2002). The maturity models work on the assumption that there are different levels of interaction with users and different degrees of integration of data that can be benchmarked. A high score is then a surrogate of a high level of sophistication in e-government.

A much less evaluated aspect and less visible aspect of e-government is the internal facet of the governments' own use and reuse of data generated, handled, and stored with IT. Scholl (2005) claims that e-government research is subject to an iceberg phenomenon. The top of the iceberg represents the government to citizen and business interaction whereas the governments' internal effectiveness and efficiency is largely disregarded because it is below the surface and therefore much less visible. We concur with his observation and add that only with an effective internal processing of information can the citizen and business be better serviced. Also in line with business process reengineering (BPR), in the public process reengineering (PPR) model formulated by Andersen (2004) it is suggested that public sector institutions should reorganize their internal activities in order to achieve effectiveness and efficiency by keeping their focus on the benefits for the users of the services. However, these two contributionsAndersen (2004) and Scholl (2005) - are exceptions from the rule of the citizen-centric approach dominating e-government research at present.

Our focus in this paper is on the internal aspect of e-government. Inspired by the recently launched government-wide eDay initiative, a review of one decade's worth of Danish policy statements is presented. The eDay initiative aimed at strengthening the intra- and interorganizational interaction through electronic means among all government departments and at all levels of government. Hence the objective of this paper is to present the impact of the strategy the Danish government has applied to strengthen the diffusion of e-government in and among public sector institutions in Denmark. Based on the figures from the years 2002, 2003, and 2004 on digital interaction, the internal digital handling of data, and finally uptake of technology supporting the digital handling, we discuss whether the agenda for diffusion of e-government has proven to be successful. When referring to e-government, the definition developed by Layne and Lee (2001) is applied. Layne and Lee suggested that e-government is

government's use of technology, particularly web-based Internet applications to enhance the access to and delivery of government information and service to citizens, business partners, employees, other agencies, and government entities (p. 123).

By using this particular definition the external customers of the public sector as well as the public sector are seen as beneficiaries of e-government adoption and diffusion. 
The remainder of the paper is as follows. Section 2 provides an overview of Danish government initiatives used to fuel the diffusion of e-government during the period from 1994 through 2003. Section 3 presents the stream of literature focusing on intervention and its use for fueling the diffusion of IS innovations. Section 4 outlines our data and discusses the impact of the eDay. Section 5 provides some concluding remarks.

\section{THE HISTORY OF INSTITUTIONAL INTERVENTION LEADING TO THE eDAY INITIATIVE}

In the Danish context, the history of institutional intervention for the support of the diffusion of IT-innovations in government dates back to 1994. In the following, excerpts of the policy statements are presented in chronological order starting with year 1994 and ending with year 2003 when the eDay initiative was launched. Not all initiatives have exclusively focused on IT adoption in the public sector. However, a particular focus on those sections concerning the public sector and its role in technology diffusion are emphasized in the presentation. We review and characterize the main initiatives and discuss their focus areas in terms of citizen-centric or focus on internal processes. All policy statements can be found at the web-site of the Ministry of Science, Technology and Innovation (www.fsk.dk under the link Publications).

\subsection{4: "Info-Society 2000"}

In 1994 the Ministry of Research published the report "Info-Society 2000." The report was a consequence of the Bangemann report (1994) prepared by the EU. The Info-Society 2000 report led to a continuous stream of initiatives all suggesting how IT should be utilized in the public sector and how proper utilization would lead to benefits for the public sector, businesses, and society as a whole.

\subsection{5: "From Vision to Action-Info-Society 2000"}

The first statement "From Vision to Action-Info-Society 2000" was published in 1995. The statement was used as a lever to create awareness of the great significance of the digital revolution. It was stated that this movement toward the Info-Society was a movement involving everybody. In a true Danish spirit, it was argued that if Grundtvig had been alive he would probably be connected to the Internet. Grundtvig (1783 to 1872) was a Danish poet, statesman, and church father. He was the driving force behind the establishment of the first Danish folk high schools. The folk high schools played a significant role in the education of rural youth until the 1950s when the governmental education system took over. This rather strong symbol illustrates the expectations for the move toward the information society, which was seen as the means for everybody to get involved in democratic processes and education. The strategy should thus be based on a Danish model where market forces should not, similar to initiatives in Italy (Kumar et al. 1998) and Hong Kong (Damsgaard and Lyytinen 1998), be allowed to be the only forces determining development. 
Although the statement primarily focused on building a strong infrastructure, the responsibility of the public sector to engage in the movement was stressed. The role of the public sector in the digitization of the Danish society was emphasized in statements such as

Public administration (central, county and municipal levels) is to be connected in a comprehensive electronic service network, providing: better service to citizens, better service to trade and industry and support of their own use of IT, rationalisation gains, and more open decision-making processes.

By implementing these electronic service networks it was expected that

Concurrently with the replacement of IT systems, public institutions are to change gradually from paper-based archives to electronic processing and filing over the coming years.

\subsection{6: "The Info-Society for All"}

In 1996, the next IT policy statement was published. The statement focused on EDI as the means to digitize the Danish society. The statement was named "The Info-Society for All-The Danish Model." In the 1996 statement, it was announced that

this new technology [EDI] presents a number of opportunities and problems, which demand political consideration and action. A cohesive, aggressive strategy for how we wish to further the developments in Denmark is necessary.

Included in this "aggressive strategy" was the 1996 action plan for electronic commerce. It was found that "the importance of a fast, effective and consistent implementation of, e.g., EDI could hardly be overestimated." First and foremost it was claimed that technological landmarks such as EDI could give Denmark an international lead along with improvement in efficiency of working procedures and development of new products and production processes. The goal of the 1996 action plan was thus to provide the necessary conditions for companies, the public sector, and, not least, the consumers to reap the gains resulting from EDI.

The plan is to provide dynamism and accelerate growth. This will be achieved through the public sector joining forces with a large number of commercial organizations to create joint solutions. Thereby we will avoid a state in which everyone waits for everyone else, or in which the approaches chosen are not coherent.

In order to create the necessary dynamics and consistency, seven initiatives were formulated. The initiatives primarily aimed at supporting the diffusion of EDIFACT based EDI communication, thereby supporting electronic data transactions between private companies and the public sector. The expectations regarding the ability of the public sector in relation to development and implementation were high. It was found that the public sector had to take the lead and show an example. 
It was acknowledged in the introduction to the 1996 action plan that the project was ambitious and that it required involvement from several business sectors and institutions. One means to meet this end was to make the necessary arrangements to be able to execute public procurement via EDI. It was, however, the adopters that carried the main responsibility for acting according to the recommendations in the action plan.

One decisive feature of "the Danish model" is that, without grandiose plans, but precisely through dialogue and effective action, we are in a position to implement the necessary infrastructure quickly and to remove the barriers to it.

This attitude was further explained by former experiences with the long Danish tradition of the establishment of the cooperative dairies and abattoirs, which successfully took place at the end of the $19^{\text {th }}$ century and which led to a social and economic lift for a large number of small and often impoverished farmers. Again, strong national symbols were taken in use to promote the diffusion of IT in the Danish society. Again, a vision was created and the actors were expected to act accordingly, but no concrete actions were taken to ensure the implementation.

\subsection{9: "Focus on e-Commerce"}

The outcome of the 1996 action plan was less successful than expected and in 1999 - one year before the planned expiration of the action plan — a new initiative was launched. This initiative was named "Focus on e-Commerce." Focus on e-Commerce was organized to meet the conditions imposed by the information society and the Internet. The aim was to initiate concrete activities, which could promote the development of electronic commerce in Denmark. The initiative consisted of seven points for action, mostly focusing on creating safe and optimal conditions for e-commerce, which peaked at that time. One of the seven points explicitly focused on "electronic commerce in the public sector."

\subsection{0: "Digital Denmark-Conversion to the Network Society"}

In year 2000, the next initiative, "Digital Denmark - Conversion to the Network Society," was announced. Five objectives were highlighted as important to digitize Denmark. Among these five objectives was "More Effective and Cheaper Service via Digital Administration," it was argued that

Efficient digital administration means, among other things, ensuring optimal internal procedures. IT should contribute to the public administration by optimising its organisation and working procedures to produce results in the form of measurable rationalisation gains. These gains will also contribute significantly to the public sector, solving the demographic problem which will mean that in a few years it will have to function with a smaller workforce. 
Similar to the previous initiatives the means for achieving the benefits were based on voluntariness. It was admitted that to reap the benefits of IT investments, it was necessary to face the organizational consequences of the technological investments.

\subsection{2: "IT for All-Denmark's Future"}

"IT for All—Denmark's Future," an IT and telecommunications policy statement and action plan from 2002, was the next initiative. The preamble stressed that IT should be the means for promoting a reform of the public sector in Denmark. It emphasized that development should still be driven by private initiative and on market terms. One outcome of this strategy was the launch of the public procurement portal (doip.dk), which was privately owned and run. Again, seven areas of importance to strengthen Denmark as an IT nation were outlined. Among these was "an IT-based public sector."

The recommendations to strengthen an IT based public sector were

(1) The public sector to work digitally both internally and in contact with citizens and companies; (2) Public service delivery to be coherent and usercentred, with greater re-use of public data and an increasing number of general portals being means to this end; (3) Focus to be intensified including organisational upgrading of IT; and, (4) Public-sector e-commerce to be initiated and substantially increased.

Some resources were granted to implement the initiatives but it was emphasized that the policy statement should be seen as an invitation to dialogue. Furthermore, a new body was introduced: the Digital Taskforce. The role of this Digital Taskforce was (and is) to ensure coordination and progress of the move toward e-government. It is a joint board including top managers from central and local government administration. One tangible outcome of the Digital Taskforce was the eDay.

\subsection{3: "eDay 1"}

The first of September 2003 was announced by the Danish government to be a special "eDay." From that day, all Danish state, regional, and local governmental authorities has the right to demand that communication with other authorities to be exchanged electronically. The practical implication of this initiative is that authorities from that day can refuse paper-based communication. The eDay initiative can be seen as a milestone in the Danish IT policy. It is the first time in the 10 years of IT policies that direct intervention is used as a means for fueling the diffusion process by creating a network effect. The eDay initiative explicitly states that public sector institutions have the right to demand that other units communicate electronically with them. Throughout the history of Danish IT policies, it has been claimed that digital communication would be beneficial for public institutions and that a shift should take place to make the Danish public sector efficient. There has been an implicit expectation that the diffusion of the 
necessary technologies would take place based on the recommendations but no direct control or enforcement has been used to make diffusion and implementation happen. Another remarkable shift in the policy is the introduction of the digital taskforce as an active change agency, stimulating the diffusion process. Section 5 analyzes if the eDay initiative actually has led to a strengthening of e-government.

This section presented the odyssey of Danish IT policy through one decade. The presentation focused on the content and also to some extent on the means for implementing the content of the policy statements. The next section focuses on the impact of policy statements as observed in previous studies.

\section{INTERVENTION AS A LEVER FOR DIFFUSION}

There are different opinions regarding the effectiveness of regulation and intervention as the means for directing action related to IT adoption. This raises the question of whether regulatory initiatives can possibly result in voluntary changes in organizational behavior leading to adoption and diffusion, or if incentives for adoption are to be found in mechanisms solely driven by economic and strategic interests. In the following, a number of considerations related to regulation are discussed. It should be emphasized that the initiatives presented above, in a legal sense, are categorized as soft law. Soft law concerns rules of conduct that are on a legally nonbinding level (Nielsen 1999). An analogy is, however, made to considerations related to explicit rules and regulation in general.

Inherent in a set of rules is the means of regulatory intervention. Three types of regulatory intervention, the pedagogical, the economic, and the normative (Eckhoff 1983) have been described as means for regulating organizational and human behavior. Prohibition and commands characterize normative interventions. Normative interventions are means for enforcing the objective of the regulation. One example of this type of intervention in relation to IT adoption is to define standards (Andersen et al. 2000). Economic interventions are characterized by influencing what people find it advantageous to do. Through economic interventions, organizations are rewarded for performing certain acts or punished for certain other types of behavior. Direct subsidy of projects can be considered an example of an economic intervention (Andersen et al. 2000). The pedagogical intervention is characterized by information campaigns initiated by governmental units and larger associations where the aim is to influence the opinion of a given group of potential adopters. Eckhoff (1983) argues that information is a must in most cases where the economic and normative regulatory interventions are brought into play, but information in itself can be used as a means of intervention.

Through information, it is possible to influence opinions and values, thus making individuals more motivated for certain types of actions wished for by the governmental units or associations. Knowledge building hence becomes an important aspect in pedagogical intervention (Andersen et al.2000). However, governments can also effectively employ institutional measures to obtain a desired change in behavior. Institutional measures are usually classified into influential or regulatory ones (King et al. 1994). Influential initiatives aim to change the behavior of those under the institution's sway. 
This is achieved without direct reference to force, or the exercise of command, but mainly through an incentive structure. Regulatory actions, on the other hand, are expected to affect directly the behaviors of entities under formal government jurisdiction. This can take the form of directives or through limiting the choice of options. Overall, regulatory measures allow conflicting decentralized decisions to be compatible without the necessity of either centralized institutions or "key" individuals to comprehend the whole system (Boyer 1988). This is sometimes necessary as, for example, the use of common standards may yield more work for each node in a system but the overall benefits clearly outweigh the sum of each node's additional work.

Within the domain of IS research, the impact of intervention is often subject to discussion. The writings of Lai and Guynes (1997), Gregor and Johnston (2001), Johnston and Gregor (2000), and King et al. (1994) uncover a discrepancy in relation to the effects of coordinated efforts made by industry and trade associations or governmental units in relation to diffusion of IT (Damsgaard and Lyytinen 2001). It has been stated that institutional (especially governmental unit) interventions (Lai and Guynes 1997) and change in the environment (e.g., regulation) (Gregor and Johnston 2001) are among the most powerful causes for IT adoption and diffusion. Deliberate institutional interventions or refraining from interventions are thus found to play a vital role in technology diffusion (King et al. 1994). The opposite point of view has, however, also been stated recently by Johnston and Gregor (2000), who argue that "deliberative coordinated action by an industry as a whole, or units purporting to represent such a group position, may be severely limited in effectiveness." Different parties can address the building of electronic infrastructures, which are a necessity for IT diffusion (Damsgaard and Lyytinen 1998).

Two of the most well-known governmental initiatives related to IT adoption and diffusion are the TEDIS project, launched by the European Commission, and TradeNet, launched by the government in Singapore. The Singaporean TradeNet was, contrary to the TEDIS project, launched as a mandatory initiative from a governmental agency, the National Computer Board. The companies involved in the export sector were obliged to implement EDI for the exchange of export documents with the public authorities. The electronic infrastructure was launched in 1989. TradeNet is the first nation-wide EDI ever implemented (Teo et al. 1997). TradeNet processed nearly all trade declaration documents by the end of 1994 . The Singapore experiment can be viewed as a success in relation to diffusion of EDI in a business community, where it has achieved or even surpassed its goals (Thong 1999). Hong Kong launched a similar initiative named Tradelink but, typical for Hong Kong, Tradelink was owned by both private and public companies. Once Tradelink was operational and proved its systems worked, the government decided to shut down the counter for manual submission of trade declarations and export/import licenses. The two Asian initiatives represent examples of normative intervention.

In the Danish context, the indirect pedagogical intervention has been the sole strategy pursued in the policy statements up to the eDay initiative where more direct intervention is taken into use (Henriksen and Andersen 2004). The following section examines if the eDay initiative has gained the same success as, for example, Singapore's TradeNet. 


\section{ANALYSIS AND DISCUSSION OF THE IMPACT THE eDAY 1}

To analyze the impact of eDay 1, statistical data were retrieved from Statistics Denmark. The analysis and discussion includes the annual accounts of the public sector's use of IT in years 2002, 2003, and 2004. The reason for using this particular sample is that consistent and comparative data were available from that time span. Given that eDay was launched in 2003, it is found suitable to use these data as the source. We believe that this data is the best option available. Another possibility would be to obtain data based on a survey instrument specifically developed for the purpose of analyzing the impact of eDay in the diffusion and deployment of IT internally in the public sector in Denmark but this approach would capture intentions and impressions only. The actual use forms a concrete measure on which the impact of eDay 1 can be observed.

The series of data from years 2002, 2003, and 2004 show that there has been a growth in the exchange of data electronically between governmental units whereas the exchange of documents between citizens and businesses and that the public sector has remained more or less constant. The growth in governmental units receiving documents electronically at the 25 percent level is statistically significant ( $p$ is less than or equal to 0.001 ). The growth is depicted in Figure 1.

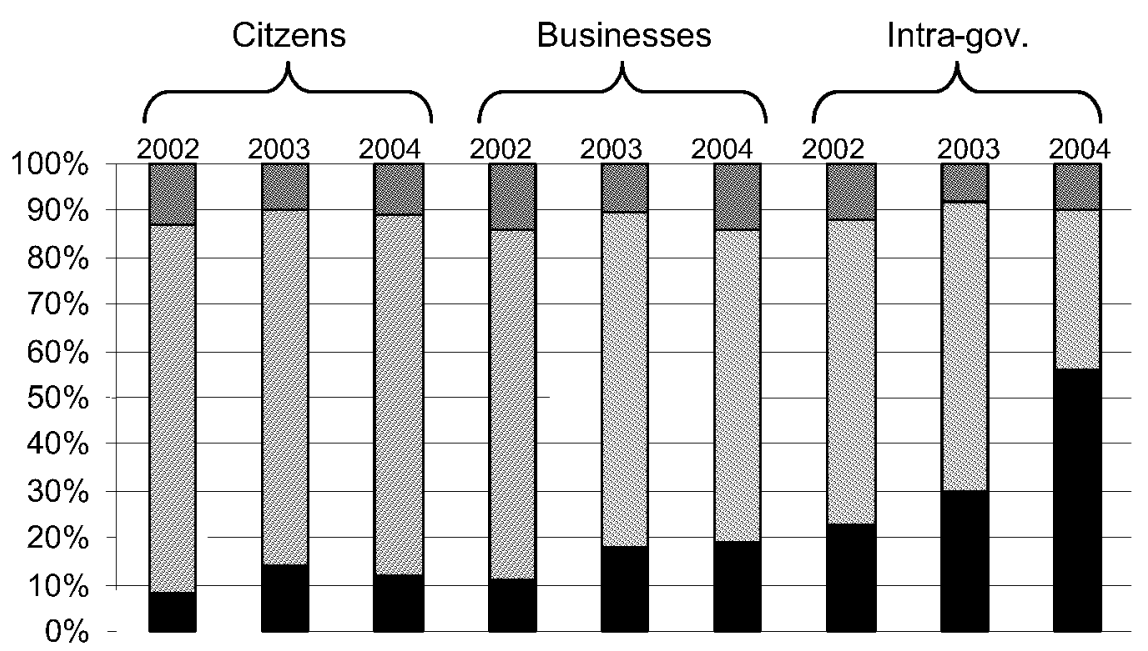

Don't know Less than $25 \%$ At least $25 \%$

Figure 1. Number of Documents Received Electronically from Citizens, Businesses, and Other Governmental Units, 2002-2004

I"Den offtenlige sektors brug af IT 2002, 2003, 2004 [Usage of IT in the Public Sector]," Statistics Denmark, www.dst.dk. 
This indicates that the eDay has had an impact on the diffusion of e-government. Public sector institutions have increased their digital interaction. Recalling that the definition used for e-government was "government's use of technology, particularly web-based Internet applications to enhance the access to and delivery of government information and service to citizens, business partners, employees, other agencies, and government entities," the implementation of e-government should also have an impact on internal working procedures. To analyze a possible impact of the growth in the number of documents being received electronically, internal electronic document handling was analyzed. Figure 2 depicts the growth in electronic document handling in the governmental units.

Figure 2 illustrates that there has only been a small growth in the number of governmental units where at least 50 percent of the cases are handled electronically. Taking into consideration that there has been a substantial growth in number of cases actually exchanged electronically intra-governmentally (see Figure 1) which is not reflected in the statistics on electronic case handling, this could indicate that the public sector institutions do not have the IT-tools necessary for handling the cases electronically. In order to analyze this closer, the uptake of case- and document-handling systems in public intuitions was analyzed.

Figure 3 depicts that the degree of sophistication on handling of electronic documents is rather low. There is a high level of deployment of electronic log-systems at all levels - and especially at the county level where the level has been 100 percent all years reported. When it comes to full electronic case handling, the deployment is rather low at the state and municipal levels. It is crucial to ask if this is due to issues related to standards.

Although there has been a significant growth in communication with other agencies in XML format during the period 2002-2004, the overall adoption rate is still low (see Figure 4). This could indicate that the Danish public sector faces a classical problem. The good will is there to adopt technology but technological infrastructures, particularly standards, are not in place.

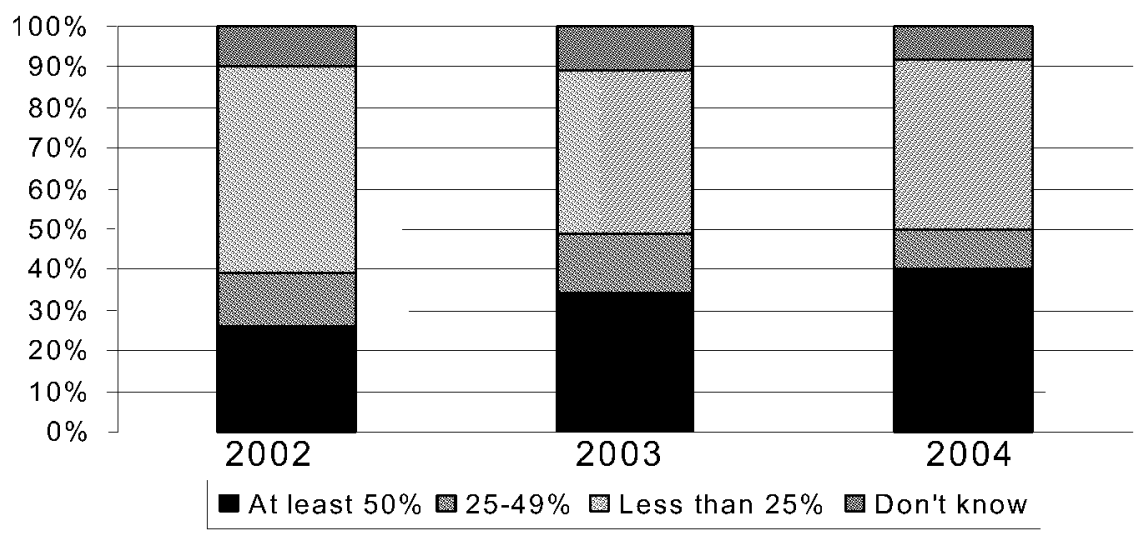

Figure 2. Number of Governmental Units Using Electronic Document Handling Systems 


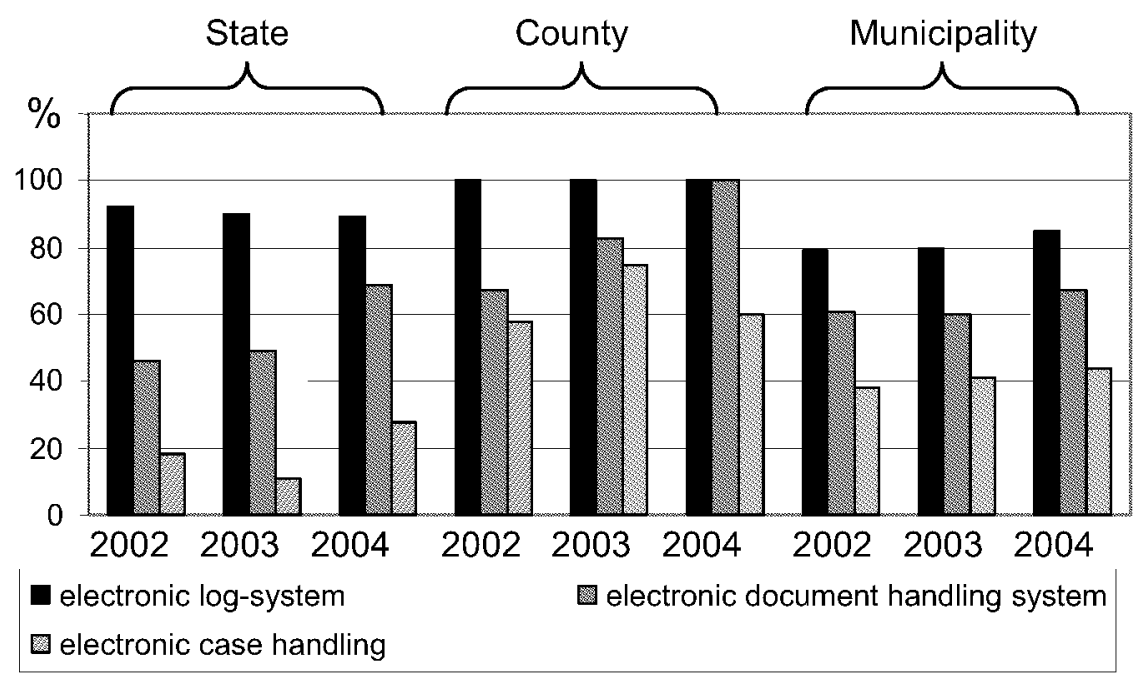

Figure 3. Deployment of Electronic Log-Systems, Electronic Document Handling Systems, and Electronic Case Handling

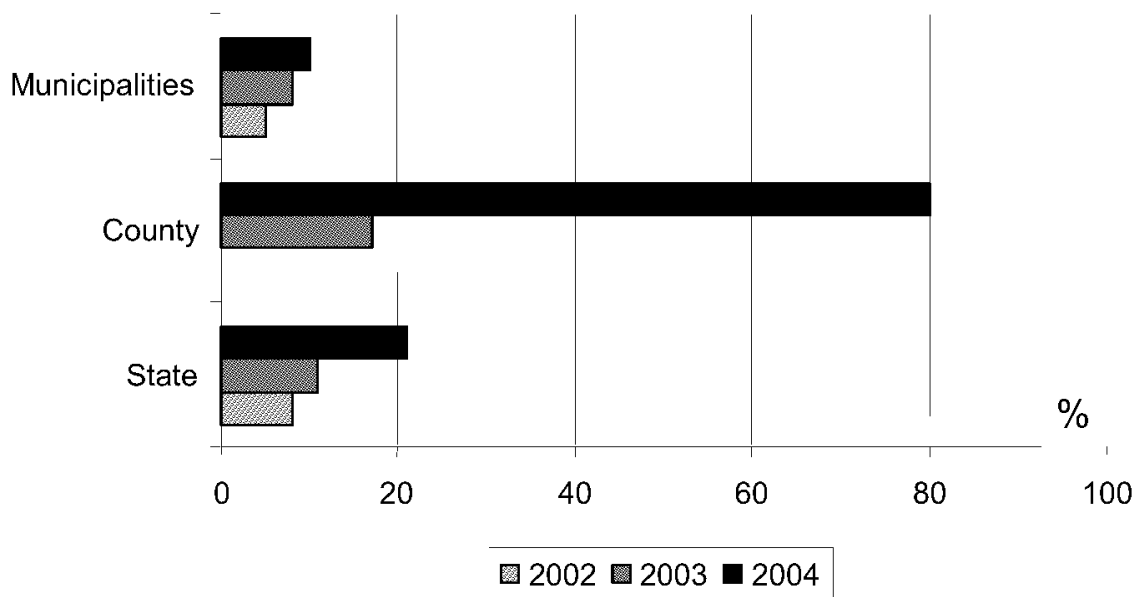

Figure 4. Communication with Other Agencies in XML Format (2002-2004)

To illustrate, the Danish Customs and Tax department introduced EDI as part of their service concept, which is to be technologically ahead of the companies they service. As a consequence, relations with the trading community improved and the image of the Customs and Tax department as a slow and dull government department shifted toward an image of a modern and progressive service organization. However, one of the main problems for the department is that, from the beginning, it allowed 
multiple standards, and multiple entries to the system, and having done that, it is now impossible for the department to reduce the number of entries and endorse only one standard. Instead, new versions are issued and new implementation guidelines are published at a high rate. So it is a tragedy that instead of helping setting a standard for EDI for the benefit of Danish companies, the customs and tax authorities add to the confusion by endorsing several standards and versions thereof.

\section{CONCLUSION AND PUTTING THE INITIATIVES INTO PERSPECTIVE}

One of the unifying principles of Danish IT policy in the domain of e-government has been to reduce the paper-based case handling in favor of electronic processing and filing. In each of the initiatives presented in section 2 , there are more or less pronounced expectations for savings and efficiency gains if the public sector changes its routines from manual paper-handling to electronic procedures. In a Social Democratic spirit, adoption and diffusion of the ideas exhibited in the policy statements have been fueled by pedagogical intervention rather than more direct means such as legislation or economic rewards for changing behavior. This path has not, so far, proven to be fruitful if conclusions are made based on the figures on IT adoption in the public sector published by Statistics Denmark.

One overall challenge in relation to assessment of the outcome of coordinated initiatives is the level of analysis when measuring the outcome. One way to evaluate the success or failure of a project is based on the project's rate of adoption among potential users. As observed by Kumar et al. (1998), this might be a less fruitful path since some or all adopters at a later state might reject the innovation. To denote adoption rate as the dependent variable for success thus has to be seen in relation to time (DeLone and McLean 1992). This approach, however, is not easy to apply to the eDay initiative at this point in time given the relatively recent inception.

Our analysis suggests that the initiative so far has led to mixed results. When looking at the intra-governmental exchange of electronic messages in isolation (see Figure 1), there has been a remarkable growth. This indicates that the eDay initiative has had a positive impact on the diffusion of e-government. But a closer examination of the further deployment of the electronic messages provides a different picture. There has only been a slight increase in the number of government agencies using electronic document handling systems, which is a prerequisite for paper-less document handling as envisioned in the policy statements. This suggests that more traditional procedures are still the norm in governmental agencies. One problem appears to be the lack of basic systems supporting electronic document and case handling (see Figure 3). Ultimately, this indicates that Danish government agencies face what the business community has suffered from for decades: lack of common standards. One future challenge for the Danish public sector in order to be able to implement e-government is, therefore, to agree on a common standard for communication and interaction to make sure that the access to and delivery of government information and service to citizens, business partners, employees, other agencies, and government entities can be enhanced. 


\section{References}

Accenture. Leadership in Customer Service: New Expectations, New Experiences, 2005 (available through http://www.accenture.com/).

Andersen, K. V. E-Government and Public Sector Process Rebuilding (PPR): Dilettantes, Wheelbarrows, and Diamonds, Boston: Kluwer Adademic Publishers, 2004.

Andersen, K. V., Juul, N. C., Henriksen, H. Z., Bjørn-Andersen, N., and Bunker, D. Business-toBusiness E-Commerce, Enterprises Facing a Turbulent World, Copenhagen: DJØF Publishers (Association of Danish Lawyers and Economists), 2000.

Bangemann, M. Europe and the Global Information Society, Brussels: European Commission, 1994 (available online at http://www.medicif.org/Dig_library/ECdocs/reports/ Bangemann.htm).

Boyer, R. "Technical Change and the Role of Regulation," in G. Dosi, C. Freeman, R. Nelson, G. Silverberg, and L. Soete (eds.), Technical Change and Economic Theory, London: Pinter Publishers, 1988, pp. 67-94.

Cap Gemini. Online Availability of Public Services: How Is Europe Progressing?, EU: DG Information and Media, March 3, 2005 (available online at http://europa.eu.int/ information_society/soccul/egov/egov_benchmarking_2005.pdf.

Damsgaard, J., and Lyytinen, K. "International Trade at the Speed of Light: Building an Electronic Trading Infrastructure in Denmark, Finland, and Hong Kong," in T. J. Larsen, L. Levine, and J. I. DeGross (eds.), Information Systems: Current Issues and Future Changes, Laxenburg, Austria: IFIP, 1998, pp. 417-438.

Damsgaard, J., and Lyytinen, K. "The Role of Intermediating Institutions in Diffusion of Electronic Data Interchange (EDI): How Industry Associations in the Grocery Sector Intervened in Hong Kong, Finland, and Denmark," The Information Society (17:3), 2001, pp. 195-210.

DeLone, H. W., and McLean, E. R. "Information Systems Success: The Quest for the Dependent Variable," Information Systems Research (3:1), 1992, pp. 60-95.

Eckhoff, T. Statens styringsmuligheter, Oslo: TANUM-NORLI, 1983.

European Union. The Role of E-Government for Europe's Future, Brussels: European Commission, 2003.

Gregor, S., and Johnston, R. B. "Theory of Interorganizational Systems: Industry Structure and Processes of Change," in R. Sprague (ed.), Proceedings of the $34^{\text {th }}$ Hawaii International Conference on Systems Sciences, 2001, pp. 159-170.

Henriksen, H. Z., and Andersen, K. V. "Diffusion of E-Commerce in Denmark: An Analysis of Institutional Intervention," Knowledge, Technology, and Policy (17:2), 2004, pp. 63-81.

Holden, S. H., Norris, D. F., and Fletcher, P. D. "Electronic Government at the Local Level: Progress to Date and Future Issues," Public Performance and Management Review (26:4), 2003, pp. 325-344.

Johnston, R. B., and Gregor, S. "A Theory of Industry-Level Activity for Understanding the Adoption of Interorganizational Systems," European Journal of Information Systems (9:4), 2000, pp. 243-251.

Kaylor, C., Deshazo, R., and Van Eck, D. "Gauging E-Government: A Report on Implementing Services among American Cities," Government Information Quarterly (18:4), 2001, pp. 293-307.

King, J. L., Gurbaxani, V., Kraemer, K. L., McFarlan, F. W., Raman, K. S., and Yap, C. S. "Institutional Factors in Information Technology Innovation," Information Systems Research (5:2), 1994, pp. 139-169.

Kumar, K., van Dissel, H. G., and Bielli, P. "The Merchant of Prato Revisited: Toward a Third Rationality of Information Systems," MIS Quarterly (22:2), 1998, pp. 199-225. 
Lai, V. S., and Guynes, J. L. "An Assessment of the Influence of Organizational Characteristics on Information Technology Adoption Decision: A Discriminative Approach," IEEE Transactions on Engineering Management (44:2), 1997, pp. 146-157.

Layne, K., and Lee, J. W. "Developing Fully Functional E-Government: A Four Stage Model," Government Information Quarterly (18:2), 2001, pp. 122-136.

Moon, M. J. "The Evolution of E-Government among Municipalities: Rhetoric or Reality?," Public Administration Review (62:4), 2002, pp. 424-433.

Nielsen, R. Retskilderne, Copenhagen: Jurist- og Økonomforbundets forlag, 1999.

OECD. World Public Sector Report 2003: E-Government at the Crossroads, New York: United Nations, 2003 (available online at http://unpan1.un.org/intradoc/groups/public/documents/ UN/UNPAN012733.pdf).

Scholl, H. J. "Organizational Transformation through E-Government: Myth or Reality?," in M. A. Wimmer, R. Traunmüller, A. Grönlund, and K. V. Andersen (eds.), Electronic Government, $4^{\text {th }}$ International Conference (EGOV 2005), Berlin: Springer, 2005, pp. 1-11.

Tan, C. W., and Pan, S. L. "Managing E-Transformation in the Public Sector: An E-Government Study of the Inland Revenue Authority of Singapore (IRAS)," European Journal of Information Systems (12:4), 2003, pp. 269-281.

Teo, H. H., Tan, B. C. Y., and Wei, K. K. "Organizational Transformation Using Electronic Data Interchange: The Case of TradeNet in Singapore" Journal of Management Information Systems (13:4), 1997, pp. 139-165.

Thong, J. Y. L. "An Integrated Model for Information Systems Adoption in Small Businesses," Journal of Management Information Systems (15:4), 1999, pp. 187-214.

United Nations. UN Global E-government Readiness Report, New York: United Nations, 2004 (available online at http://unpan1.un.org/intradoc/groups/public/documents/un/ unpan021888.pdf).

\section{About the Authors}

Helle Zinner Henriksen is assistant professor at the Department of Informatics, Copenhagen Business School. She has a M.Sc. in law from University of Copenhagen and a Ph.D. from the Department of Informatics, Copenhagen Business School. Her Ph.D. is in the field of Management of Information Systems with particular interest on the implications of institutional intervention with respect to interorganizational adoption and diffusion. Her research interests include adoption and diffusion of IT in the private and the public sector. She has presented her work at international conferences including DEXA eGov, eChallenges, ECIS, HICSS, and IFIP 8.6 and in international journals such as Communication of the AIS, Knowledge, Technology, and Policy, Scandinavian.Journal of Information Systems, and International Journal of Electronic Government Research. More details on research activities and publications can be found at www.HelleZinnerHenriksen.info. Helle can be reached at hzh.inf@cbs.dk.

Jan Damsgaard is professor at the Department of Informatics, Copenhagen Business School, Denmark. He holds a Master's degree in Computer Science and Psychology and a Ph.D. in Computer Science (1996). JD is the study director of a graduate program in e-business. His research focuses on the diffusion and implementation of networked and standard-based technologies such as intranet, extranet, Internet portals, EDI, and advanced mobile services (GSM/ GPRS/EDGE, UMTS, WiFi, and WiMax). In much of his research, JD seeks to explain technology diffusion using network economics and technology characteristics. He is the research director of the Mobiconomy and DREAMS projects that focus on diffusion and implementation of advanced mobile services. He has presented his work at international conferences (ICIS, ECIS, PACIS, HICSS, IFIP 8.2., and IFIP 8.6) and in international journals (European Journal of 
Information Systems, Information Systems Journal, Journal of Strategic Information Systems, Information Society, Journal of Global Information Management, Journal of Organizational Computing and Electronic Commerce, Information Technology and People, and Journal of the Association for Information Systems). JD can be reached at damsgaard@cbs.dk or at http://www.cbs.dk/staff/damsgaard/. 